\title{
Peace parks in Southern Africa: bringers of an African Renaissance?*
}

\author{
Marloes van Amerom† and Bram Büscher $\ddagger$
}

\section{A B S T R A C T}

The pursuit of an African Renaissance has become an important aspect of regional cooperation between South Africa and its neighbours. Transfrontier conservation areas, or 'Peace Parks' as they are popularly called, have been identified as key instruments to promote the African Renaissance dream, and are increasingly advocated and justified on this basis. By fostering joint conservation (and tourism) development in Southern Africa's marginalised border regions, Peace Parks are claimed to further international peace, regional cooperation and poverty reduction, and thus serve basic ideals of the African Renaissance. This article critically explores this assumption. Using the joint South African-Mozambican-Zimbabwean Great Limpopo Park as a case study, it argues that in reality the creation of Peace Parks hardly stimulates and possibly even undermines the realisation of the African Renaissance ideals of regional cooperation, emancipation, cultural reaffirmation, sustainable economic development and democratisation. So far, their achievement has been severely hindered by domination of national interests, insufficient community consultation, and sensitive border issues such as the illegal flows of goods and migrants between South Africa and neighbouring countries. Furthermore, exacerbation of inter-state differences induced by power imbalances in the region, and harmonisation of land use and legal systems across boundaries, are increasingly becoming sources of conflict and controversy. Some of these problems are so severe, we conclude, that they might eventually even undermine support for African Renaissance as a whole. Utmost care is thus required to optimally use the chances that Peace Parks do offer in furthering an African Renaissance.

\section{N T R O D U C T I O N}

Africa in the Ig9os has seen the initiation of a wide range of ideologyladen concepts that seek to both capture and stimulate the continent's

* We would like to thank William Critchley, Stephen Turner, Chris Reij, Harry Wels, Bernhard Venema, the Amsterdam Institute for International Development and two anonymous referees for their valuable contributions to this article.

$\dagger$ Department of Sociology, University of Edinburgh, United Kingdom.

\$ Centre for International Cooperation, Vrije Universiteit Amsterdam, the Netherlands. 
development. This article deals with the linkages between two such concepts: 'Peace Parks' and 'African Renaissance'.

Peace Parks are biodiversity and wildlife conservation areas that straddle the boundaries of, and are managed in common by, two or more countries. Although the notion of transboundary conservation emerged in the early i930s, it really started taking off on a global scale - using the term Peace Parks - from the mid I9gos onwards. The African continent, notably Southern Africa, shares enthusiastically in designating and developing nature areas across international borders, in order to create environmental economies of scale. ${ }^{1}$ However, not all Transboundary Protected Areas (TBPAs) are Peace Parks. In addition to environmental goals, the 'establishment, creation or strengthening of international friendship' (Shine 1997) is an explicit aim of Peace Parks, as is the sustainable economic development of the communities living in or around the area. Because of their ability to unite these widely diverging goals into one concept, Peace Parks have attracted considerable foreign donor and media attention, leading to significant financial support for their development. $^{2}$

Another ideology-laden concept, much broader in scope, is 'African Renaissance', championed foremost by the South African President Thabo Mbeki. Generally understood as a 're-birth' or 'resurrection' of the African continent, the African Renaissance concept is promoted as an ideological umbrella, an overarching response to the wide array of problems plaguing the continent that stimulates Africans to come up with 'African solutions for African problems'. Although there is much debate as to what this entails, the main focus is on issues like regional cooperation, the emancipation of disadvantaged groups, sustainable economic development, and the deepening and sustenance of democracy. While the initial hype around the concept has died down, the African Renaissance is still promoted with vigour and acts, no matter how elusive it might be, as a philosophical or ideological basis for the development policies of many influential African actors. Although both 'African Renaissance' and 'Peace Parks' are 'buzzwords', each uniting many goals in one concept, it is clear that African Renaissance entails a more abstract idea than Peace Parks. Hence, it is argued that Peace Parks can act as concrete tools for realising the dream of the African Renaissance. Indeed, advocates of Peace Parks are increasingly promoting and justifying the concept on this basis.

In this article, we critically examine this assumption, and investigate whether Peace Parks can contribute significantly to an African Renaissance. Drawing on closer inspection of the two concepts, and using the joint 
South African-Mozambican-Zimbabwean Great Limpopo Peace Park as a case study, we argue that the creation of Peace Parks hardly stimulates or may actually undermine the realisation of the African Renaissance ideals of regional cooperation, cultural reaffirmation, emancipation, sustainable development and democracy. Although plans for Peace Parks can be found throughout Africa, the focus of this article is on Southern African Peace Parks. Following South Africa's transition to democracy in 1994, most of the region has been relatively stable and generally has a higher level of affluence than the rest of the continent. ${ }^{3}$ Together with the personal commitment of many highly influential actors, these constitute important underlying reasons why the southern part of the continent especially has engaged in promoting and developing Peace Parks.

\section{A F R I C A N R E N A I S A N C E}

The African Renaissance (AR) concept has been debated intensely for some years, and there seem to be no signs of fatigue yet. Much has been said about the concept, and we do not aim to give an in-depth analysis of the debate here. Rather, we aim to provide a brief overview that will help us understand the roots of the concept, its dominant themes, and how the African Renaissance has been operationalised.

The African Renaissance concept has firm roots in the history of the African continent. Mzamane (200I) even traces its spirit back to the first rebellion of African slaves in the 'new world' in the late eighteenth century. This and similar events, according to him, were the first breeding grounds for pan-Africanism, the term that is generally regarded as an important predecessor of, and source of inspiration for, African Renaissance (Landsberg \& Kornegay I998; Hottinger 1999; Landsberg \& Hlophe i999). The vision of pan-Africanism, most eloquently articulated during the wave of political independence in the I96os by the likes of Kwame Nkrumah and Julius Nyerere, imagined a 'United States of Africa', undivided by arbitrarily drawn borders imposed by outsiders. Only through such a union could Africa 'become one of the greatest forces for good in the world'. Otherwise, Africa would stay 'weak' and 'divided' (Nkrumah I96I). Even though the realisation of the idea of pan-Africanism waned quickly after it was first introduced, the dream of a united Africa has always inspired and been kept alive by many proponents of Africa's development.

The roots of AR can be traced to African uprisings or struggles against 'traumatic epochs'; from the system of slavery in the eighteenth and nineteenth centuries and the European colonisers in the nineteenth and 
twentieth centuries, to the structural neo-colonialist imbalances in the world economic and political system that started in the ig6os and last until today. ${ }^{4}$ This is reflected in the present-day struggle of the African continent to overcome hardships such as 'unstable political systems', 'predatory elites', a high 'international debt burden', and unfavourable international trade regimes. Together these and other constraining factors have resulted in further 'declines in the standard of living and the quality of life for hundreds of millions of Africans' (Mbeki I999). Dating from the I990s, this modern use of the African Renaissance concept is often said to have been initiated by South African President Thabo Mbeki in his address to a summit in Virginia, USA in 1997 on 'attracting capital to Africa' (Mabogo 2002; Vale \& Maseko I998). ${ }^{5}$ Since then, it has become a popular buzzword, used opportunistically by many different actors in both public and private realms, especially in South Africa (Maloka 2000).

What then does the African Renaissance concept in its present form entail? By all accounts this is not clear, as the term lacks a clear definition or description. Vale and Maseko (1998) suggest that the features of the African Renaissance are kept deliberately vague to create space for mobilising people for a wide variety of issues important to the elites championing the AR concept. Because a wide range of actors, from politicians and policymakers to businessmen and scholars, are using the concept, the fear of AR becoming a container-concept, in which everything fits, effectively losing all meaning, is not unreal. ${ }^{6}$ Nevertheless, several dominant themes recur in the African Renaissance vocabulary. Four are usually distinguished: (I) emancipation of suppressed or disadvantaged groups in society (e.g. women, minorities and youth); (2) a reaffirmation and increased inter-exchange of African cultures; (3) sustainable economic development; and (4) broadening, deepening and sustenance of democracy (Mavimbela I998; Vale \& Maseko I998). From the perspective of AR as a successor to the pan-Africanist idea, we argue that a fifth theme should be added: regional cooperation and a desire for a pre-colonial concept of borders (see also Griggs 1997). According to its proponents, if the African Renaissance is to succeed and the twenty-first century is to become 'an African century' (Mbeki 1997), it has to take into account and simultaneously address these five issues.

Besides defining dominant themes in the African Renaissance jargon, we need to explore the conceptual dimensions of AR in order to arrive at a deeper understanding as to whether the Peace Parks concept could function as a tool to stimulate an African Renaissance. Vale and Maseko (I998) distinguish between two distinct interpretations of the future within the African Renaissance language. The first one is what they call a globalist 
interpretation. AR in this strand links Africa's future to dominant Western narratives such as liberalisation, privatisation and stabilisation, thus embracing a modernist concept of globalisation. The emphasis here is on 'economistic' market logic and liberal individualism, which should lead to sustained economic growth and wealth accumulation. The second AR interpretation of the future is what Vale and Maseko term Africanist. This strand calls for a more post-structural interpretation of AR, emphasising African identity and culture. Africanists want Africa to take its future truly into its own hands by making use of the wealth of knowledge that Africans possess instead of being directed by Western notions of progress or 'civilisation'.

Despite attempts to direct the African Renaissance dream into a third way, between the globalist and Africanist interpretations (Cheru 2002), the dominant reading of African Renaissance, we agree with Vale and Maseko, is the globalist one. All the major proponents of AR phrase the concept in such a way that, although it sounds reactionary, it does not contrast with foreign donor 'guidelines' and hinges closely on the neo-liberal globalisation lexicon of the developed Western world. An explanation for this can be found by taking a closer look at who the major proponents of the African Renaissance are. Disproportionately, they are leading politicians, members of the business community and influential individuals from Africa's most powerful country, namely South Africa, with President Thabo Mbeki as its absolute champion. ${ }^{7}$ Hence, it is critical to note that besides being a South African invented and driven philosophical concept for the whole of Africa, African Renaissance is at the same time also a South African 'emerging foreign policy doctrine' consisting of 'a set of foreign policy goals and domestic styles and politics entrenched in a set of political, social and economic relations' (Landsberg \& Hlophe I999: I). This dominance in the 'ownership' of the AR concept gave South Africa a great edge in determining its operationalisation.

South Africa's upper hand in operationalising the African Renaissance has forced the country to try to balance pressures from domestic constituencies with interests from other parts of Africa. That the domestic constituencies, especially the business community that works according to the interests of transnational capital, seem to have gained a dominant leverage is not at all surprising (Taylor \& Williams 200I). South Africa in the globalist reading could 'come to anchor a chain of economies which, with time, might become the African equivalent of the Asian Tigers', whereby South Africa acts as 'the agent of globalisation' and 'the continent will offer South Africa a preferential option on its traditionally promised largesse of oil, minerals and mining' (Vale \& Maseko i998: 277). 
Without wanting to disregard genuine Africanist AR desires, this is attractive for South African political leadership, and thus the globalist African Renaissance outlook of Mbeki and others does not seem illogical.

Departing from this stance, South Africa constantly tries to engage its African partners to embrace the African Renaissance concept, and help design or designate vehicles to aid implementation. Pivotal in this are actors such as Nigeria (Darah 2000), and prominent statesmen such as Presidents Museveni of Uganda, Kagame of Rwanda and Aboulaye Wade of Senegal, representing the 'new generation of African leaders' (Ottaway 1998). Important vehicles that have been designed or designated to carry out the African Renaissance vision are the African Union (AU), the New Partnership for Africa's Development (NEPAD), the Southern African Development Community (SADC), the Economic Community of West African States (ECOWAS), and the Common Market for Eastern and Southern Africa (COMESA). Although of a different stature, transboundary Peace Parks have also been designated as an important vehicle to stimulate an African Renaissance. The next step is to delve deeper into what they entail.

PEACEPARKS IN SOUTHERN AFRICA

The Peace Parks concept is part of a distinctive group of phenomena interlinking biodiversity conservation and borders. Other similar concepts are Transfrontier Conservation Areas (TFCAs), Transfrontier Parks (TFPs) and Transboundary Protected Areas (TBPAs). The difference between 'park' and 'area' is that a 'park' adheres to one land-use option (usually strict conservation), while an 'area' combines multiple land-use options in one locale (for instance, conservation areas, hunting concession grounds, and community-based natural resource management areas). While these various terms are often used interchangeably, it is important to note that there are subtle differences between them (Wolmer 2003).

The term 'TFCAs' has been in existence the longest and is widely used internationally. 'TBPAs' emanated from 'TFCAs' and is typical Southern African jargon aimed at claiming more ownership over the transboundary conservation movement (Wolmer 2003). While both these terms still fairly neutrally describe the object in question, the 'Peace Parks' concept brings the terminology to a new and politically motivated epistemological level. By adopting the term Peace Parks, transboundary conservation has joined the arena of other elusive development concepts such as 'sustainable development', 'community ownership' and 'good governance', which share a similar all-embracing motivational purpose. While these concepts seemingly offer intellectual space for a wide variety of different interests, 
actors and outcomes, they are often operationalised on the basis of one specific ideology (neo-liberalism), leading to very specific (neo-liberal) outcomes (Wolmer 2003; Büscher \& Mutimukuru 2004). In this article, we refer predominantly to Peace Parks and TBPAs, but always with reference to the above remarks.

Although it is beyond the scope of this article to give a historical overview of the interface between environment and development in Africa, we have to note that Peace Parks do not occur in a historical vacuum. ${ }^{8}$ Rather, they are arguably the latest phase in a long and often unfortunate history of environment and development in Africa, in which the interests of the native African inhabitants have regularly been suppressed by colonial or neo-colonial interests in the protection of Africa's wildlife and the economic exploitation of Africa's natural resources (Gibson i999; Adams \& Hulme 200I). Moreover, although community-based participatory approaches constitute the current conservation paradigm, conservation practice continues to be entrenched in old colonialist protectionist approaches that propagate the separation of local people from the nature and wildlife they depend on for their livelihoods (Adams \& Hulme 200i). ${ }^{9}$ Hence, nature conservation in Africa is a very sensitive issue, and Peace Parks must be understood within this historical framework.

Since the mid-nineties, the concept of Peace Parks has been so dominantly voiced from Southern Africa that many believe it to originate from that region (Michler 2003). Nonetheless, Peace Parks are far from unique to Southern Africa. Their origins can be traced back to the establishment of the US-Canadian Waterston/Glacier Park in 1932. ${ }^{10}$ This was the first genuine Peace Park: a transboundary protected area created with the explicit aim of promoting peace between countries. The term 'Peace Parks' can be traced to the Ig8os, when the World Conservation Union (IUCN) actively started promoting 'parks for peace' on international boundaries (Sandwith int. 2002), or 'Peace Parks'. From there, the concept quickly gained in importance. In I988 there were 59 established and potential border parks, and the number had grown by i997 to I36 actual and potential TBPAs, straddling i 2 international borders in 98 countries (Zbicz \& Green I997: I58). This rise in (potential) TBPAs has been matched by an increased interest in the capacities of TBPAs to promote international friendship and understanding. In Southern Africa, the notion of Peace Parks quickly gained momentum after the improvement in the relations between South Africa and neighbouring countries following the end of apartheid in I994. So far, most efforts have focused on six identified Peace Parks in the region. The first Peace Park in Southern Africa was the Kgalagadi Transfrontier Park between South Africa and Botswana, 
T A B LE I

Southern Africa's most advanced Peace Parks

\begin{tabular}{|c|c|c|c|}
\hline & Name & Countries Involved & Status \\
\hline I & $\begin{array}{l}\text { Great Limpopo } \\
\text { Transfrontier Park }\end{array}$ & $\begin{array}{l}\text { South Africa } \\
\text { Zimbabwe } \\
\text { Mozambique }\end{array}$ & $\begin{array}{r}\text { Treaty signed } \\
\text { on } 9.12 .2002\end{array}$ \\
\hline 2 & $\begin{array}{l}\text { Kgalagadi } \\
\text { Transfrontier Park }\end{array}$ & $\begin{array}{l}\text { South Africa } \\
\text { Botswana }\end{array}$ & $\begin{array}{l}\text { Officially opened } \\
\text { on } 12.5 .2000\end{array}$ \\
\hline 3 & Ai/Ais-Richtersveld Park & $\begin{array}{l}\text { South Africa } \\
\text { Namibia }\end{array}$ & $\begin{array}{l}\text { Treaty signed } \\
\text { on I.8.2003 }\end{array}$ \\
\hline 4 & $\begin{array}{l}\text { Maloti-Drakensberg Transfrontier } \\
\text { Conservation and Development } \\
\text { Area }\end{array}$ & South Africa & $\begin{array}{l}\text { Memorandum of Understanding } \\
\text { signed on II.6.200I }\end{array}$ \\
\hline & & Lesotho & \\
\hline 5 & Limpopo-Shashe TFCA & $\begin{array}{l}\text { South Africa } \\
\text { Botswana } \\
\text { Zimbabwe }\end{array}$ & $\begin{array}{l}\text { Draft Memorandum of } \\
\text { Understanding under discussion }\end{array}$ \\
\hline 6 & Lubombo TFGA & $\begin{array}{l}\text { South Africa } \\
\text { Mozambique } \\
\text { Swaziland }\end{array}$ & $\begin{array}{l}\text { Trilateral Protocol signed } \\
\text { on } 22.6 .2000\end{array}$ \\
\hline
\end{tabular}

established on 12 May 200o. Of the other five, the Great Limpopo Park between South Africa, Mozambique and Zimbabwe is the most advanced in terms of development into a fully established and operational Peace Park. So far, an international treaty has been signed, parts of the boundary fence between Mozambique and South Africa have been removed to allow for the migration of wildlife from South Africa into Mozambique, and active joint management of the area is being developed. The remaining four TBPAs are in various stages of progress, as indicated in Table $\mathrm{I}$.

At the moment, these six Peace Parks can be considered as either established TBPAs or as progressing seriously towards that status. Fifteen other prospective Peace Parks (of which only two or three have shown signs of progress) have been identified by the Peace Parks Foundation, a nongovernmental organisation (NGO) created with the purpose of stimulating and facilitating the development of Peace Parks in the region. What is remarkable about this table is that South Africa is involved in all southern African TBPAs that we consider as progressing seriously. This is mainly because South Africa has far more capacity in economic, organisational and financial terms to put the idea of Peace Parks into practice than other southern African countries. Again, as with the African Renaissance 
concept, this gives South Africa an edge in operationalising the Peace Parks concept, which, as we shall see when we discuss the Great Limpopo Park, can and does have major implications for the balance between implementing partners who should in theory be equal.

In a region prone to conflict over land (Bradshaw \& Ndegwa 2000), several rationales account for the creation of Peace Parks on vast areas of private, state and community owned land. Firstly, such Transboundary Protected Areas initiatives are motivated by the conviction that bigger parks will foster more effective biodiversity management, allowing for the restoration of traditional wildlife migration routes and an ecosystem approach. Secondly, the creation of 'superparks' is expected to stimulate ecotourism. On this basis, Peace Parks have been promoted as an important means to further sustainable economic growth in Southern Africa's marginalised borderlands. Thirdly, by means of Community Based Natural Resource Management (CBNRM) policies, these economic benefits are explicitly promoted as benefiting local communities, thus stimulating the emancipation of economically marginalised groups. Finally, TBPAs are expected to act as vehicles for peace by enhancing regionalisation through institutionalised cross-border cooperation and (more) open border policies. An illustration of this is the decision of the Southern African Development Community (SADG) to promote TBPAs as a key principle in wildlife management for its member states. ${ }^{11}$ These four rationales all hinge very closely on the dominant themes of the African Renaissance that we have outlined above, thus providing a logical basis for the comparisons that are often made between the two concepts.

Beyond the popular use of the concept, the notion of Peace Parks is often advanced by Southern African politicians as a policy concept that reflects traditional African wildlife practices, cultural values and pre-colonial 'border' customs (Asiwaju I983; Van der Linde et al. 200I). This last point is illustrated by the notion that TBPAs could in practice function as 'frontier zones' representing a return to pre-colonial border constructs, whereby the precise line of the boundary is said to be relatively unimportant. In African Renaissance language, Peace Parks are thus represented as a truly African solution to African problems such as (border) conflicts and underdevelopment. From a political public relations point of view, in order to mobilise people, this is of course a tactical and smart move. But it is highly questionable whether this representation has any credibility. Firstly, TBPAs and Peace Parks originate from North America and can be found all over the world, and as such can hardly be called truly African. Secondly, the whole Peace Parks process in Southern Africa is largely 
driven by a very specific set of political and business elites, ${ }^{12}$ and it is questionable whether they are best suited to represent 'true African' interests.

Nevertheless, this has not stopped these actors from claiming ownership of the Peace Parks concept, and even trying to 'export' it to the rest of the world. ${ }^{13}$ In this new malleable 'package' form, the potential benefits that can be derived from Peace Parks are seemingly unending, with benefits over a wide range of political, economic, ecological and social strata. To quote Nelson Mandela (200I):

I know of no political movement, no philosophy, no ideology, which does not agree with the peace parks concept as we see it going into fruition today. It is a concept that can be embraced by all. In a world beset by conflict and division, peace is one of the cornerstones of the future. Peace parks are a building block in this process, not only in our region, but potentially in the entire world.

Furthermore, Peace Parks are sold in glossy and modern media that are easy for the popular press to pick up, by prominent people such as Nelson Mandela, the late Prince Bernhard of the Netherlands, and the influential South African businessman and founder of the Peace Parks Foundation, Anton Rupert.

So far, this campaign to sell the 'Peace Parks product' seems to be working. The widespread popularity of the concept of Peace Parks has attracted a wide range of donor agencies (such as the World Bank, USAID and the German KFW - Kredietanstallt für Wiederaufbau), NGOs and private sector interest. Even the United States Congress recently officially approved of the concept. ${ }^{14}$ However, reflecting Africa's weak position in the international system (Clapham I996) the funding provided by Western donors such as the World Bank and the United States Agency for International Development (USAID) has also meant that pressure was applied for the concept of Peace Parks to be operationalised on the basis of dominant Western economic paradigms that, like the dominant 'globalist' interpretation of African Renaissance, reflect the neo-liberal outlook of the Washington consensus. Thus, privatisation, free trade, private land ownership and the commercialisation of conservation have increasingly become important cornerstones of Peace Parks. Moreover, as is so often the case, the practice of Peace Parks increasingly contrasts with its rhetoric. The next section illustrates this in more depth, through a case study of the Great Limpopo Peace Park. With the huge expectations surrounding it, the Great Limpopo has become a 'make it or break it case' (Braack int. 2002) that will determine the success of the Peace Parks concept in practice, and hence the contribution that Peace Parks can make to an African Renaissance. 
The Great Limpopo Transfrontier Park is a joint agreement between South Africa, Mozambique and Zimbabwe. Its origins date back to the nineteenth century, when a Portuguese ecologist, Gomes de Soussa, proposed that the Limpopo area, divided by English and Portuguese colonial administrations, could be more effectively managed and conserved as one integrated ecosystem (Draper \& Wels 2002). The basic idea of the present Great Limpopo Park still relates to this old idea: a connection between the South African Kruger Park and the Mozambican Limpopo Park, with an extension to the Zimbabwean Gonarezhou Park by means of the Sengwe corridor.

The treaty for the 35,000 square km Great Limpopo Park was signed in December 2002, but the first cross-border transfer of wildlife from South Africa to Mozambique had already taken place in October 200I. The establishment of the transboundary Park is denoted as only a step in the process of creating the Great Limpopo Transboundary Conservation Area, consisting of multiple land uses and, with a staggering ıоo,ooo square kilometres, envisaged to become the biggest TBPA in the world. This makes for great eco-tourism appeal and subsequent expectations for social benefits arriving from more open boundaries for many 'transnational communities' in the area. The cooperation between South Africa, Mozambique and Zimbabwe in the Great Limpopo is often heralded as an important step towards regional integration and is often presented as the flagship of an African Renaissance. For example, Valli Moosa (200I), South Africa's Minister of Environmental Affairs and Tourism, calls the Great Limpopo a 'demonstrable manifestation of the African Renaissance'. And this has been put even more strongly by South African President Thabo Mbeki (2002): 'This Transfrontier Park says that each passing day transforms the dream of an African Renaissance into reality.'

In reality, however, more and more difficulties are emerging around the project. The next section critically assesses the contribution that the Great Limpopo has so far made in furthering the objectives of the African Renaissance. For purposes of clarity and comparison, we will assess the role of the Great Limpopo for each of the identified main cornerstones of the African Renaissance: (I) regional cooperation; (2) emancipation; (3) revaluation of African cultures; (4) sustainable economic development; and (5) democratisation.

\section{Regional cooperation}

The Great Limpopo represents a form of regional cooperation par excellence, and as such could fulfil an important role as instigator 
of an African Renaissance. But adherence to the envisaged, and from the African Renaissance viewpoint crucial, principles of solidarity and equity between the partner states has proved problematic. This is reflected in struggles over the sharing of benefits between South Africa and neighbouring countries and over land harmonisation policies.

The sharing of the Great Limpopo's expected ecotourism benefits on the basis of equity has proved difficult to realise (Braack int. 2003). While Mozambique and Zimbabwe initially envisaged that the total income of park fees would be shared by all three countries, South Africa, whose Kruger Park is by far the most profitable of the areas involved, insisted that each country would be entitled to keep its own revenues. The issue was eventually resolved in favour of the South African viewpoint (Fakir 2003). Even though this particular dispute has ended, such conflicts linger on in institutional memories, and influence the further course of the process. For example, months-long delays on the Mozambican side in signing the Treaty of the Great Limpopo, exploding the initial time schedule, were in large measure caused by Mozambican anger over South African 'dominance' in the Great Limpopo (DEAT int. 2002).

Mozambique and Zimbabwe, moreover, fear that South Africa will benefit disproportionately from the Great Limpopo, because its domination of the region's tourist industry could result in much of the income generated by ecotourism on their territories flowing back to South Africa. ${ }^{15}$ This risk is especially apparent if the Great Limpopo park really develops into a full-scale transboundary conservation area, allowing South Africa to offer a more diversified tourism package featuring not only parks, but also Mozambique's beaches. South Africa in contrast argues that its Kruger Park, which already attracts over a million tourists a year, will function as 'an ideal springboard for increasing tourism throughout the rest of the TFCA' (GLTP n.d.). However, with the commercial sale of tenders in the Great Limpopo regulated through free competition, the chances are high that the majority of these will end up in the hands of South African 'big business', including those in areas now serviced by Zimbabwean or Mozambican businesses (Fakir 2003: 20; Munthali \& Soto 2001: 24-5). Perceptions in Mozambique and Zimbabwe that South Africa will benefit the most from the creation of the Great Limpopo, even at the expense of its partners, have been further reinforced by South Africa's construction of a new airport near Nelspruit. ${ }^{16}$ This diminishes the chances for Maputo international airport to become the main entry gate for tourism to the Great Limpopo (Ramutsindela 2004). 
The harmonisation of land use in the Great Limpopo is another issue creating significant tensions. The South African Kruger Park observes a preservationist management regime, allowing no-one to hunt in the park or to reside there (other than park staff). Mozambique's Limpopo Park, on the contrary, is home to an estimated I5,000 people, mostly former refugees of the Mozambican civil war (Koch int. 200I). In addition, the northern part of Zimbabwe's Gonarezhou Park has been 'invaded' by local communities (Nielsen \& Chikoko 2002), in spite of earlier pledges of Zimbabwean President Mugabe in presidential meetings on the Great Limpopo that the Gonarezhou Park would not be affected by his radical land redistribution programme (DEAT int. 2003) ${ }^{\mathbf{1 7}}$ Endowing each country with the right to administer its own area (Treaty 2002: 8), the international treaty on the Great Limpopo suggests that the linkage of the three respective conservation areas into the Great Limpopo will not produce power struggles. However, due to the increased ecological and economic interdependency that TBPAs generate, Peace Parks increase the chances that countries will try to influence the administration of land in a neighbouring country to avoid having to change their own.

Up to now, land harmonisation in the Great Limpopo has particularly been an issue between South Africa and Mozambique. ${ }^{18}$ An example of this is the creation of wildlife corridors between South Africa's Kruger Park and Mozambique's Limpopo Park. With the South African Kruger Park suffering from elephant overpopulation, these wildlife corridors aid South African wildlife management by relocating 'excess elephants'.19 However, South Africa fears that the communities staying in the Mozambican part of the Great Limpopo may poach the Kruger elephants for their ivory (Peddle et al. 2003). To avoid this, the South African Department of Environmental Affairs (DEAT) and the Peace Parks Foundation now seek 'to see communities relocated to areas outside it' (Munthali \& Soto 200I : I3; see also University of the Witwatersrand 2002). Mozambique's proclamation of the conservation oriented Limpopo National Park, replacing the Coutada i6 hunting area that allowed sustainable use of natural resources and the presence of human settlements, can partially be interpreted as Mozambique giving in to South African pressure. South Africa has requested Mozambique to fence off its Limpopo Park for similar purposes and this stance tends to be supported by one of the most important foreign donors to the Great Limpopo, the German KfW (Grossman int. 2003). These developments have raised concerns in Mozambique that participation in the Great Limpopo could lead to loss of sovereignty (Van Amerom 2002). 


\section{Emancipation}

With many poor and disadvantaged groups located in and around the Great Limpopo, the Park offers ample opportunities to further the emancipation objective of the African Renaissance. Governments and other actors realise this and in many official documents, local communities are indeed represented as the main beneficiaries of the Great Limpopo (see RSA DEAT 2004).

Despite these intentions, it has so far proved difficult to translate the creation of the Great Limpopo into improved livelihood prospects for local communities. Promises of a better economic life have so far not been fulfilled and perhaps seem further away than ever. There are several reasons for this. First, the donor funding for the Great Limpopo has thus far predominantly been directed towards wildlife management, especially to elephant relocations (Collins int. 2002). Second, predictions of a massive increase in tourism to the Great Limpopo are proving to have been premature and exaggerated (Katerere et al. 2001 : 19-20; Schoon 2004: 19). Even when the Transfrontier Park is fully operational, the generation of jobs and income through increased ecotourism to the park is likely to remain highly limited or non-existent for local communities. It has never been explicitly stated precisely how much communities can expect, and therefore they can make few formal demands. Third, it is important to note that the number of local people surrounding the Great Limpopo is relatively high. The area bordering the south and west of the Kruger Park alone hosts 6 million people, forcing the added advantages to be divided among so many people that the increased benefits per person may well be negligible. Lastly, business considerations and social welfare are not necessarily complementary. Recent developments in the Kruger Park illustrate this point; 66o Kruger Park employees were retrenched in 200 I as part of privatisation strategies (Wildnet Africa 200I). The majority of them were unskilled workers from neighbouring communities (Themba int. 200I).

The creation of the Great Limpopo may even become disadvantageous to the livelihoods of communities, especially those living within it. As indicated above, communities that do not hold formal land rights are threatened with a loss of their land. Commercial interests in the exploitation of yet 'undeveloped' park areas may accelerate the erosion of community land rights. This is reflected in competing claims on land bordering the Shinguedzi River in the Mozambican part of the Great Limpopo. Most community settlements in the Limpopo Park are in this area, with the river making for relatively fertile land and good herding 
opportunities. However, it is precisely these areas that are also the most attractive ones for the development of tourism lodges, because of beautiful scenery and a relatively high occurrence of wildlife along the river. Not surprisingly, private investors are now starting to claim these areas (Theron int. 2002).

\section{Reaffirmation of African cultures}

The creation of the Great Limpopo could make an important contribution to the revival of traditional African cultural values and has been presented as such. Because it would allegedly 'bring down the fences', the Great Limpopo could enhance cultural and social exchange between transnational ethnic groups like the Shangaan, and thus stimulate a cultural renaissance in the area. Indeed, the 'resumption - or at least legalisation of cross border movement of tribal groups divided by international boundaries' to 'integrate scientific understanding and indigenous knowledge' initially constituted an important planning objective of the tri-national park (Anon: 5, our italics).

However, the formation of the Great Limpopo has not improved crossborder access for local communities. The envisaged removal of boundary fences has done little for local people, as they are still not allowed to cross the international boundaries within the Great Limpopo Park. Improved cross-border access for people at the moment mainly focuses on the needs of international tourists, with cars, to cross the border. Linked to this, the removal of borders is often detrimental to the geopolitical interests of one or more of the states involved. Discussions over changes in border policies have so far particularly focused on the complexities in the MozambicanSouth African borderland. A removal of boundary fences might increase illegal migration from Mozambique, which is considered undesirable by South Africa (Koetzer int. 200I). Even more importantly, illegal car trafficking is prominent in the borderlands between South Africa and Mozambique. A removal of boundaries coupled with the creation of a cross-border road network connecting the various parts of the Great Limpopo carries the risk that, once established, the Great Limpopo could become a gateway for this illegal activity (Peddle et al. 2003). As a result, the South African police and other security agencies successfully campaigned for the maintenance of the border fence between the Kruger Park and the Mozambican Limpopo Park, coupled with an increase of internal border posts in the Great Limpopo. At the same time, the fence has been cut in some places to allow for the migration of wildlife. These passages are, however, not to be used by the local population. Nor, lastly, are the 
opportunities that exist to foster cultural exchange between South African and Mozambican local communities through the Great Limpopo stimulated by plans to relocate the communities out of the Limpopo Park.

Considering border access between communities in Zimbabwe and their counterparts in Mozambique and South Africa, we must conclude that there has not been much improvement there either. Although the Sengwe community, which owns the land in the Sengwe corridor between the Kruger National Park and the Zimbabwean Gonarezhou Park, intends to join the Great Limpopo, the Zimbabwean government has still not formally consulted this community to enable its involvement in accordance with Zimbabwean law. Removal of the boundary fence between South Africa and Zimbabwe is also hampered by the fact that it acts as an important barrier to the spread of veterinary diseases, such as bovine tuberculosis in buffalo (Ramutsindela 2004: 69) and foot and mouth disease. Finally, out of fear of spill-over effects from the political violence in Zimbabwe, such as increasing flows of refugees and arms, South Africa and Mozambique are currently pursuing policies that make it increasingly difficult for Zimbabwean citizens to cross the border into these countries. Both countries are therefore unlikely to accede in the short term to open border policies with Zimbabwe in the Great Limpopo.

\section{Democratisation}

All the participating governments subscribe to democratisation and decentralisation of power and decision-making to the community level within the implementation process of the Great Limpopo (Anon. 2000). In practice, however, national governments have been reluctant to decentralise power to the local level and community participation in TBPAs has remained mere 'window-dressing' (Mayoral-Philips 2002). This is in part because governments see themselves as the only actors with a negotiating mandate where transnational issues are concerned (Büscher \& Dietz forthcoming 2005). Communities were therefore not invited to take part in official negotiations or have a seat in the International Technical Committee (ITC), which drafted the conceptual plan, the action plan and the trilateral agreement for the Great Limpopo. The ITC did try several times to raise community interests and promote participation, but this was always either insufficient or refused (Braack int. 2003; Grossman int. 2003).

One means of promoting democratisation in the Great Limpopo process has been through the establishment of community forums. However, the respective governments are not formally obliged to consult these 
before undertaking action. This means that in practice communities are often only informed of the plans of their governments after these have already become official policy (Nkatini int. 200I). A striking example concerns the communities in the Mozambican Limpopo Park, most of which were kept uninformed of the translocation of 25 Kruger elephants into their territory (University of the Witswatersrand 2002). Nor, of course, do plans for communities to be resettled out of the Mozambican part of the Great Limpopo constitute democratic practice.

Even where local communities have relatively strong rights to land and representation, the exercise of their rights in the Great Limpopo tends to remain highly limited. The position of the South African Makuleke aptly illustrates this point. Although the recognised owners of part of the land to be included in the TBPA, they are not treated as equal partners in the Great Limpopo (Steenkamp \& Urh 200o). They have no direct representation in the Technical Committee. Nor are they allowed their own community forum group, which means that their rights are represented by the general community forum, alongside communities that do not own land in Kruger and as such have different priorities and rights. South African Minister Valli Moosa's refusal to allow community representatives access to a top meeting of the three ministers for environmental affairs on the Great Limpopo in July 2000 is another indication of the low position that local communities occupy within the Great Limpopo's organisational and institutional framework (Braack int. 2003). Altogether, this evidence supports the conclusion, also drawn by Dzingirai (2004), that, rather than democratisation and decentralisation, Peace Parks seem to promote greater inequality between governments and communities or a 'disenfranchisement at large'.

\section{Sustainable economic development}

As most Peace Parks have conservation as their dominant objective, the sustainable part in sustainable economic development is usually emphasised strongly (Rozemeijer int. 2003). In the Great Limpopo, biodiversity goals are generally being achieved. Biodiversity and wildlife are already quite well conserved in South Africa's Kruger Park, and the Limpopo Park in Mozambique is now slowly being restocked through elephant and other wildlife transfers from the Kruger National Park. Not all is positive though. The recent unrest in Zimbabwe has resulted in decreasing levels of biodiversity in its Gonarezhou Park. Combined with the past influx of people into Gonarezhou, this could negatively affect biodiversity levels throughout the Great Limpopo. 
What then about the 'economic' in sustainable economic development? The generation of economic development appears less straightforward than originally presented. We identify five reasons. Firstly, although the Great Limpopo has attracted millions in funding, ${ }^{20}$ little of this appears sustainable, involving one-off grants and donations from international donors. Private sector investment has, contrary to what was hoped, remained low in the Great Limpopo. Secondly, as noted before, estimates that the Great Limpopo would raise millions of US dollars in tourism income turned out to be overly optimistic. Thirdly, it is important to note that the tourism industry is highly sensitive to political unrest (Duffy 2002). The political crisis in Zimbabwe has led to a dramatic decline in tourism to that country. When it became clear that Zimbabwe's Gonarezhou Park would join the Mozambican and South African parts of the Great Limpopo, it was feared that tourists might also avoid these areas out of fear of spill-over effects from the violence in Zimbabwe. Fourthly, as has been highlighted above, the regional distribution of economic benefits is far from equal, with South Africa enjoying the great majority. Finally and most importantly, what about the immense pressure on the park created by the millions of people living on the borders of the Great Limpopo? If this pressure does not somehow decrease, opportunities to sustain sustainable economic development will be very limited.

CONGLUSION : PEAGE PARKS AS B RINGERS

OF AN AFRICAN RENAISSANGE?

This article has scrutinised the assumption that Peace Parks constitute a key instrument in promoting the realisation of the African Renaissance. Looking at the current situation in the Great Limpopo, the flagship of TBPAs in Southern Africa and an alleged main driver of the African Renaissance, we must conclude that Peace Parks so far contribute little to the goals of an African Renaissance.

As we have discussed, an African Renaissance wishes to accomplish: (I) emancipation of suppressed or disadvantaged groups in society; (2) a reaffirmation of and stronger ties between African cultures; (3) sustainable economic development; (4) broadening, deepening and sustenance of democracy; and (5) regional cooperation. Although Peace Parks have the potential to further these objectives, the social, infrastructural, ecological, economic and institutional changes introduced by Peace Parks have as yet done little to this end. As a case study of the Great Limpopo has shown, Peace Parks can and often do exacerbate inequalities both between states and between local communities and national governments. Community 
participation has often been mere 'window-dressing', and the notion that Peace Parks promote and facilitate cross-border access for borderland communities has increasingly been replaced by ' higher political priorities' like the security interests of states. Furthermore, there is even concern about the outright undermining of land rights of local communities in the process. This leads us to the conclusion that the emancipation, cultural reaffirmation and democracy objectives of the African Renaissance are as yet not furthered by Peace Parks.

The contribution that Peace Parks have made to regionalisation has also been limited. Attempts at harmonisation of laws and land use across boundaries have proved difficult at best, and Peace Parks have not yet achieved a different border arrangement. Even worse: on the ground there has hardly been any implication for borders, other than the release of elephants and other wildlife. There is thus little sign of regionalisation through Peace Parks, certainly not to the level of realising part of an African Renaissance.

The case study of the Great Limpopo even suggests that Peace Parks could eventually undermine the ideals of the African Renaissance. Three main reasons can be put forward. Firstly, South Africa's dominance of the Peace Parks process has led to perceptions in neighbouring countries that it is trying to play 'Big Brother'. This confirms viewpoints in neighbouring countries that the African Renaissance is really a cloak for South African political and economic 'imperialism', rather than a means to promote pan-African regional cooperation on an egalitarian basis. It also makes cooperation in the region more difficult and could fuel conflict. Secondly, as a result of the lack of community participation in and limited economic benefits from Peace Parks, community commitment to 'sustainable development' and transboundary cooperation as a whole is likely to decrease. As a result, indispensable grassroots support for the African Renaissance may be dwindling. Finally, the dominance of political and business elites and the donor-driven nature of Peace Parks undermine the notion of 'African solutions for African problems', and hence the ideals of African self-determination and self-sufficiency. A 'globalist' embedding of Peace Parks will definitely not lead to an enhanced 'Africanist' African Renaissance.

Not all is negative, though. It must be recognised that Peace Parks have laid some important foundations for an African Renaissance. More crossborder cooperation has certainly been achieved, and this could prove to be very valuable in the long term. Despite attracting less ecotourism than expected, the income and jobs generated by Peace Parks may still make an important contribution to arid and marginalised border regions. These 
potential contributions should be emphasised, so that they can be further developed. Cooperation in Peace Parks, like any large-scale development process, has its learning curves. Several policy instruments, such as those for conflict mediation, could be developed to facilitate cooperation in Peace Parks.

To ensure that Peace Parks and the African Renaissance can grow more 'towards each other', substantial institutional changes would be required in Southern Africa, not least in the sphere of regional cooperation. As fundamental power imbalances in the region inhibit Peace Parks' potential to contribute to the African Renaissance, an overarching regional entity could take the lead in areas that are politically sensitive. It must, however, be given the power and authority to do that. Even though the Southern African Development Community (SADC) is unofficially very much involved and is trying to outline a macro-framework in which Peace Parks can develop, more formal arrangements are needed to ensure that SADC can mediate in conflicts and facilitate co-ordination in the SADG region. The prominent place of Peace Parks in the NEPAD initiative could also be used. It would be advisable to have more reflective monitoring and evaluation guidelines and procedures in place to try and ensure a more democratic decisionmaking process and efficient usage of resources in Peace Parks. By making Peace Parks one of the areas within NEPAD that are open to external evaluations, connecting Peace Parks to NEPAD could ensure adherence to the agreed procedures.

\section{NOTES}

I. This relates to the bioregionalism debate. See Fall 2003 for an overview of that debate in relation to transboundary protected areas.

2. For example, the GEF donated US\$15.24 million through the World Bank to the development of the Maloti-Drakensberg TBPA (see World Bank web site).

3. Zimbabwe has of course become the notable exception in this respect.

4. This is especially how South African president Thabo Mbeki (I999) likes to portray the AR historically.

5. Compare Dunton (2003), who attributes the first use of the term African Renaissance to Nelson Mandela, at the Organisation of African Unity (OAU) summit in I994.

6. We found most of the literature or information on the African Renaissance to be very normative. Because of its 'broadness', the AR concept is often moulded to fit the author's personal or professional interests.

7. Several studies indicate that the ANC, despite its revolutionary origin and popular character, has a 'globalist outlook' on many issues. See for example Tsheola 2002.

8. For a critical overview of the history of conservation and development in Africa, see Adams \& Hulme 200 .

9. Some authors even argue that the conservation development discourse is making a U-turn to colonial fortress conservation policies. See Wilshusen et al. 2002, Büscher \& Dietz forthcoming 2005.

Io. In addition to ecological considerations, the park was created as an enduring monument 'to the long-existing relationship of peace and goodwill between the people of and Governments of Canada and the United States' (Shine I997: 37). 
I I. See SADC Protocol on Wildlife Conservation and Law Enforcement in Southern Africa and the Protocol on Shared Watercourses (available from: http://www.sadc.int/index.php).

I2. These political and business elites include all heads of state of Southern Africa and leaders of industry. The latter are predominantly from the extraction of natural resources (De Beers, Remgro, Kumba, Total), luxury goods and infrastructure (Venfin, Vodafone Group, Daimler Chrysler, Cartier), and ecotourism industries. See the Peace Parks Foundation web site.

I3. See for instance the Peace Parks Foundation web site, which relates the story of Nelson Mandela going to North and South Korea to promote setting up a Peace Park there in order to promote peace and better international cooperation. Also, Dr. Anton Rupert, chairman and founder of the Peace Parks Foundation, in his 'chairman's message' states that 'the idea has been enthusiastically supported on most continents, lately especially in the United States, South America and Europe'.

I4. On I6.7.2003 the US Congress adopted a special resolution 'supporting the efforts of the Peace Parks Foundation to facilitate the development of Transfrontier Conservation Areas in Southern Africa' (Afrikom 2003), 'US Congress support for Peace Parks' (Press release for the Peace Parks Foundation, available from: www.cpnp.co.za/newsforum/I7072003.htm).

I5. See note I3. In addition, GLTP n.d. stipulates that 'From a tourism perspective, the key components in the GLTP are Kruger National Park and the Makuleke region in South Africa, which have more than Ioo years of tourism development and currently host more than one million visitors a year.' With a comparative advantage of this kind, as opposed to little (Zimbabwe) and almost no tourism infrastructure (Mozambique), there are solid grounds for Zimbabwe's and Mozambique's stated fear.

I6. Personal observation during the first author's attendance at two policy workshops aimed at developing a management plan for the Great Limpopo (then still called the Gaza-Kruger-Gonarezhou Park), held in Skukuza, 24-27.7.200I and Johannesburg, I4.8.200I.

I7. Recent news, however, indicates that the settlements in the Zimbabwean Gonarezhou Park are now slowly being dismantled (Financial Gazette 22.I.2004).

I8. In spite of earlier arrangements with Mozambique and South Africa, the Zimbabwean government has not yet formally consulted the Sengwe community on their preferences regarding the Great Limpopo. This in turn has prevented the planned linkage of Zimbabwe's Gonarezhou Park to the Great Limpopo Park by means of the Sengwe Corridor, to the dismay of tourism authorities in Mozambique and South Africa (Chikanga 2004).

I9. Interestingly, the opportunity offered by the Great Limpopo for relocating excess elephants from Kruger Park is officially only stated once, in DEAT 2002: I6: 'This park [the Great Limpopo] is particularly exciting because it will re-establish to some extent, ancient migratory routes for various animals, and relieve wildlife population pressure, notably for elephants'. Since then, as far as we know, it has never been stated as an official aim of the Great Limpopo.

20. Including for example a donation of SAR 42 million (approximately $€_{5.4}$ million) from the German KfW Development Bank. Other major sponsors include the IUCN, the World Bank and the Dutch World-wide Fund for Nature (WWF). Each of these provided over SAR Ioo.ooo in sponsorship for the translocation of Kruger elephants in the Mozambican part of the Great Limpopo in 200 for example. See PPF website and 'They made it possible', acknowledgement of sponsors of the translocation of elephants to Mozambique, 4.I9.200I, on DEAT website.

\section{R E F E R E N C E S}

Adams, W. \& D. Hulme. 200I. 'Conservation and community: changing narratives, policies \& practices in African conservation', in D. Hulme \& M. Murphree, eds. African Wildlife and Livelihoods: the promise and performance of community conservation. Oxford: James Currey.

Anon. 2000. 'Conceptual plan for the establishment of the proposed Gaza-Kruger-Gonarezhou transfrontier conservation areas', document for presentation to the ministers responsible for wildlife in Mozambique, South Africa and Zimbabwe, 2.5.2000.

Asiwaju, A. I. I983. 'The concept of frontier in the setting of states in pre-colonial Africa', Présence Africaine 127/8: 43-9.

Bradshaw, Y. \& S. N. Ndegwa, eds. 200o. The Uncertain Promise of Southern Africa. Bloomington, IN: Indiana University Press.

Büscher, B. E. \& T. Mutimukuru. 2004. 'Buzzing too far? The ideological echo of the global governance agenda on community based forest management initiatives: a case of Mafungautsi Forest in Zimbabwe', paper presented at Ioth biennial conference, International Association for the Study of Common Property, Oaxaxa, Mexico, 9-13 August. 
Büscher, B. E. \& T. Dietz. forthcoming 2005. 'Conjunctions of governance: the state and the conservation-development nexus in Southern Africa', special issue of the Fournal of Transdisciplinary Environmental Studies, Roskilde: Roskilde University.

Cheru, F. 2002. African Renaissance: roadmaps to the challenge of globalisation. London: Zed.

Chikanga, K. 2004. 'Zimbabwe denies scuppering of development of transfrontier park', Business Report, 18.4.2004, available from Zimbabwe Situation website.

Clapham, C. 1996. Africa and the International System: the politics of state survival, Cambridge University Press.

Darah, G. G. 2000. 'Quest for the African Renaissance', The Guardian (Johannesburg), 2.I0.2000.

Draper, M. \& H. Wels. 2002. 'South African dreams: the mythology of community development in transfrontier conservation areas in southern Africa', discussion paper prepared for the seminar 'Ecotourism and Nature Parks in Southern and Eastern Africa', I2.I I.2002, African Studies Centre, Leiden University, available from Leiden website.

Duffy, R. 2002. A Trip Too Far: ecotourism, politics \& exploitation. London: Earthscan.

Dunton, G. 2003. 'Pixley Kaisaka Seme and the African Renaissance debate', African Affairs 102, 409: $555-73$.

Dzingirai, V. 2004. Disenfranchisement at Large: transfrontier zones, conservation and local livelihoods. Harare: IUCN ROSA.

Fakir, S. 2003. 'From sweet talk to delivery: community participation in transfrontier conservation areas (TFCAs)', in L. E. O. Braack \& T. Petermann, eds. 2003. Transboundary Protected Areas: guidelines for good practices and implementation. Unpublished report, Zschortau, Germany: Internationale Weiterbildung und Entwicklung (InWEnt), I5-24.

Fall, J. J. 2003. 'Planning protected areas across boundaries: new paradigms and old ghosts', fournal of Sustainable Forestry I7, I/2: 8I-IO2.

Financial Gazette (Harare). 2004. 'Government relocating illegal Gonarezhou settlers', 22.I.2004.

Gibson, C. C. 1999. Politicians and Poachers: the political economy of wildlife policy in Africa. Cambridge University Press.

Greater Limpopo Transfrontier Park (GLTP). n.d. 'General Inquiries', folder published jointly by the Limpopo National Park (Mozambique), Kruger Park (South Africa), and Gonarezhou Park (Zimbabwe), and sponsored by the Peace Parks Foundation.

Griggs, R. 1997. 'Boundaries for an African Renaissance: reshaping the continent's political geography', Track Two 6, 2. Cape Town: Centre for Conflict Resolution.

Hottinger, J. T. 1999. 'The "African Renaissance" or Africa's renewed pride in a globalized world', unpublished paper, available on Federalism website.

Katerere, Y., R. Hill \& S. Moyo. 200I. 'A critique of transboundary natural resource management in Southern Africa', Paper No I, IUGN-ROSA Series on Transboundary Natural Resource Management, available from IUCN-ROSA website.

Landsberg, C. \& D. Hlophe. 1999. 'The African Renaissance as a modern South African foreign policy strategy', Paris: CERI, 30.9.1999.

Landsberg, C. \& F. Kornegay. I998. The African Renaissance: a quest for pax Africana and Pan-Africanism, Occasional Paper I7, Braamfontein: Foundation for Global Dialogue.

Mabogo, P. M. 2002. 'African Renaissance: the politics of return', African Fournal of Political Science 7, 2: 6I-80.

Maloka, E. 2000. 'The South African "African Renaissance" debate: a critique', in E. Maloka \& E. le Roux, eds. Problematising the African Renaissance. Pretoria: Africa Institute of South Africa.

Mandela, N. 200I. Speech at the ceremony for the translocation of Kruger Park elephants into Mozambique, October 4, Kruger Park.

Mavimbela, V. 1998. The African Renaissance: a workable dream. Occasional Paper 17. Braamfontein: Foundation for Global Dialogue.

Mayoral-Phillips, A.J. 2002. 'Transboundary areas in Southern Africa: meeting the needs of conservation or development?', paper presented at the Ninth Conference of the International Association for the Study of Common Property, Victoria Falls, Zimbabwe, I7-21.6.2002.

Mbeki, T. I997. Address to corporate council on Africa's 'Attracting Capital to Africa' summit, April 19-22, Chantilly, Virginia, USA.

Mbeki, T. 1999. Speech at the launch of the African Renaissance Institute, October II, Pretoria.

Mbeki, T. 2002. Speech at the ceremony for the signing of the treaty on the Great Limpopo between Mozambique, South Africa and Zimbabwe, December 9, Xai-Xai.

Michler, I. 2003. 'Bring down the fences', Africa Geographic, March: 79-84. 
Moosa, V. 200i. Speech at the ceremony for the translocation of Kruger Park elephants into Mozambique, October 4, Kruger Park.

Munthali, S. M. \& B. Soto. 200r. 'Overt and latent conflicts associated with the establishment, development and management of the Great Limpopo Transfrontier Park', Transfrontier Conservation Areas Secretariat, Maputo, Mozambique.

Mzamane, M. V. 200I. 'Where there is no vision, the people perish: reflection on the African Renaissance', Working Paper Nr. I6. Magill: Hawke Institute, University of South Australia.

Nielsen S. \& H. Chikoko. 2002. 'The Great Limpopo Transfrontier Park, how great is the idea?', Neresletter of the Southern Africa TBNRM Network I, I: 6-7/I I.

Nkrumah, K. I961. I Speak of Freedom: a statement of African ideology. London: Heinemann.

Ottaway, M. I998. 'Africa's "New Leaders": African solution or African problem?', Current History 97, 6r9: 209-13.

Peace Parks Foundation. 2003. 'US Congress supports Peace Parks', press release, 17.7.2003, available from Peace Parks Foundation website.

Peddle, D., L. E. O. Braack, T. Petermann \& T. Sandwith. 2003. 'Security issues in the planning and management of transboundary protected areas', in L. E. O. Braack \& T. Petermann, eds. 2003. Transboundary Protected Areas: guidelines for good practices and implementation. Unpublished report, Zschortau, Germany: Internationale Weiterbildung und Entwicklung (InWEnt).

Ramutsindela, M. 2004. 'Glocalisation and nature conservation strategies in 2ist-century Southern Africa', Tijdschrift voor Economische en Sociale Geografie 95, I: 61-72.

Republic of South Africa, Department of Environmental Affairs and Tourism (RSA DEAT). 2002. 1999-20oo Annual Report. Pretoria: DEAT.

Republic of South Africa, Department of Environmental Affairs and Tourism (RSA DEAT). 2004. 'People, parks and transformation in South Africa: a century of conservation, a decade of democracy'. Pretoria: DEAT.

Schoon, M. L. 2004. 'Do peace parks harm more than they help? The role of peace parks in improving robustness in Southern Africa', Bloomington, IN: Indiana University website.

Shine, C. I997. 'Legal mechanisms to strengthen and safeguard transboundary protected areas', in Parks for Peace: international conference on transboundary protected areas as a vehicle for international cooperation. Conference Proceedings. Somerset West, I6-18 September.

Steenkamp, C. \& J. Urh. 2000. 'The Makuleke land claim: power relations and CBNRM in a South African case study', IIED Evaluating Eden Programme, Occasional Paper 18. London: IIED.

Taylor, I. \& P. Williams. 200I. 'South African foreign policy and the Great Lakes crisis: African Renaissance meets vagabondage politique?', African Affairs Ioo, 399: 265-86.

Treaty. 2002. Treaty between the Government of the Republic of Mozambique, the Government of the Republic of South Africa and the Government of the Republic of Zimbabwe on the Establishment of the Great Limpopo Transfrontier Park. Pretoria: RSA Dept of Tourism \& Environmental Affairs.

Tsheola, J. 2002. 'South Africa's form of globalisation: a continental posture paradox for insertion and dependence', Political Geography 21, 6: 789-8II.

University of the Witswatersrand. 2002. A Park for the People? Great Limpopo Transfrontier Park-community consultation in Coutada I6, Mozambique. Johannesburg: University of the Witswatersrand Refugee Research Programme.

Vale, P. \& S. Maseko. 1998. 'South Africa and African Renaissance', International Affairs 74, 2: $27 \mathrm{I}-88$.

Van Amerom, M. 2002. 'National sovereignty \& transboundary protected areas in Southern Africa', Geojournal 58: 265-73.

Van der Linde, H., J. Oglethorpe, T. Sandwith, D. Snelson \& Y. Tessema. 20or. Beyond Boundaries: transboundary natural resource management in sub-Saharan Africa. Washington, DC: Biodiversity Support Program.

Wildnet Africa News Archive. 200I. 'Kruger Park head received death threats after retrenchments', available from Wildnet Africa website.

Wilshusen, P. R., S. R. Brechin, C. L. Fortwangler \& P. C. West. 2002. 'Reinventing a square wheel: critique of a resurgent "protection paradigm" in international biodiversity conservation', Society and Natural Resources 15, I: 17-40.

Wolmer, W. 2003. 'Transboundary conservation: the politics of ecological integrity in the Great Limpopo Transfrontier Park', Fournal of Southern African Studies 29, I: 26I-78.

Zbicz, D. \& M. Green. I997. 'Status of the world's protected areas', Parks 7, 3: 5-Io. 


\section{Newspapers}

Financial Gazette, Harare; The Guardian, Johannesburg.

\section{Interviews}

Braack, L., former coordinator of the Great Limpopo Park/consultant on TBPAs, 13.9.2002 \& I5.II.2003, Pretoria.

Collins, S., GTZ, II.12.2002, Pretoria.

DEAT int. 2002: Anonymous, Department of Environmental Affairs \& Tourism, South Africa.

DEAT int 2003: Anonymous, Department of Environmental Affairs \& Tourism, South Africa.

Grossman, D., ecologist, independent consultant and community representative, involved in drafting management plans for Limpopo, Zinave and Banine National Parks (Mafisa Consultancy/David Grossman \& Associates). I6.II.2003 \& II.2.2004, Johannesburg.

Koch, E., environmental consultant and community representative (Mafisa consultancy). 6.7.200I, Johannesburg.

Koetzer, O., Inspector, South African Police, 7.9.200I, Skukuza.

Nkatini, N., head of community forum in Great Limpopo, 4.I0.200I, Kruger Park.

Rozemeijer, N., CBNRM advisor, SNV Botswana (until December 2003), 2I.II.2003, Gaborone.

Sandwith, T., task force coordinator transboundary parks (IUCN), former project officer Maluti/ Drakensberg (Kwa Zulu Natal Nature Conservation Board), 27.II.2002, Golden Gate.

Themba, Solly, assistant manager community facilitation for South African National Parks, 5.9.200I, Skukuza.

Theron, P., former Great Limpopo coordinator (South African National Parks), 22.8.2002, Pretoria.

\section{Web sites}

Federalism

Indiana University

IUCN-ROSA

Leiden, African Studies Centre

Peace Parks Foundation

RSA, Dept of Environmental

Affairs \& Tourism

Southern Africa Development

Community

Wildnet Africa

The World Bank

Zimbabwe Situation
www.federalism.ch/FTP-Mirror/ircc/InHouseSeminar/

JulianHottinger_AfricanRenaissance.pdf.

www.indiana.edu/ iupolsci/Ggradcv/shoon/peaceparks.pdf. www.iucnrosa.org.zw/tbnrm/publications_content.html www.asc.leidenuniv.nl

www.peaceparks.org

www.environment.gov.za

www.sadc.int

www.wildnetafrica.com/wildlifenews/200I/o7/I53I.html www.worldbank.org

www.zimbabwesituation.com/aprı_2004.html\#linkI 